\title{
A Role MOdEL FOR CHINA? EXCHANGE RATE FLEXIBILITY AND MONETARY POLICY IN JAPAN
}

\author{
GUNTHER SCHNABL \\ CHRISTIAN DANNE
}

\author{
CESIFO WORKING PAPER NO. 2051 \\ CATEgory 6: MONETARy POLICY AND INTERnational FinanCE \\ JULY 2007
}

An electronic version of the paper may be downloaded

- from the SSRN website:

www.SSRN.com

- from the RePEc website:

Www.RePEc.org

- from the CESifo website:

www.CESifo-group.de 


\title{
A ROLE MODEL FOR CHINA? EXCHANGE RATE FLEXIBILITY AND MONETARY POLICY IN JAPAN
}

\begin{abstract}
Few papers have tried to project how Chinese monetary policy will behave under flexible exchange rates. As Japan provides an important role model for China, this paper studies the role of the yen/dollar exchange rate for Japanese monetary policy after the shift of Japan from a fixed to a floating exchange rate regime. The econometric estimations allow for regime shifts in the impact of the exchange rate on monetary policy. The results show that the exchange rate had a substantial impact on Japanese monetary policy in periods of appreciation. This implies rising uncertainty and that repeated attempts to soften the appreciation pressure by interest rate cuts have led Japan into the liquidity trap.
\end{abstract}

JEL Code: E43, E52, E58, F31, F41.

Keywords: Yen, Yuan, Japan, China, monetary policy, exchange rate regime.

\author{
Gunther Schnabl \\ Leipzig University \\ Marschnerstr. 31 \\ 04109 Leipzig \\ Germany \\ schnabl@wifa.uni-leipzig.de
}

\author{
Christian Danne \\ University Pompeu Fabra \\ Ramon Trias Fargas 25-27 \\ 08005 Barcelona \\ Spain \\ christian.danne@upf.edu
}

June 25, 2007 


\section{INTRODUCTION}

An increasing number of papers are discussing the pros and cons of more exchange rate flexibility of the Chinese yuan (Goldstein 2003, Cheung, Chinn and Fujii 2005, Cline 2005, Frankel 2006, McKinnon and Schnabl 2006, Goodfriend and Prasad 2007 among others). Proponents of a flexible yuan have stressed the need for macroeconomic flexibility in the economic catch-up process of the Chinese economy (Goldstein 2003, Frankel 2006). Given buoyant capital inflows it has been argued that a substantial appreciation of the Chinese yuan would help to prevent a possible overheating of the Chinese economy and to correct the trade imbalance between China and the US (Goldstein 2003).

In contrast, proponents of the Chinese dollar peg have argued that the stability of the Chinese yuan against the dollar had a stabilizing impact not only for China itself but for East Asia as a whole (McKinnon 2004). The reason is that growth tends to be led by exports and China's fast rising international assets are denominated in foreign currency (McKinnon and Schnabl 2004). Furthermore, McKinnon and Schnabl (2006) have argued that for countries in the economic catchup process fixed exchange rates provide a more stable framework for the adjustment of labour and asset markets. They argue that Japan's repeated attempts to soften (productivity driven) appreciation pressure by interest rate cuts have led Japan into the liquidity trap.

Up to the present, comparatively few papers have focused on the question of how Chinese monetary policy is likely to behave under a flexible exchange rate regime. Japan provides an important case study for the prospects of the Chinese monetary policy under a freely floating exchange rate for at least four reasons. First, like in China today, growth in Japan has been traditionally led by exports (McKinnon and Ohno 1997). Second, like Japan China is an important saving surplus country and has accumulated large stocks of dollar denominated international assets (McKinnon and Schnabl 2004). Third, Japan has shifted from a fixed to a flexible exchange rate regime in the early 1970s which is recommended for China today. Forth, back in early 1970s up to the late 1980s Japan was in the economic catch-up process like China is today.

In this context we are interested in the question of if and how in Japan "fear of appreciation" affected the Bank of Japans' interest rate decisions. A substantial number of previous studies (Clarida, Galí and Gertler 1998, Chinn and Dooley 1998, Hutchison 1988, Henning 1994, Funabashi 1988, McKinnon and Ohno 1997, Esaka 2000, Hillebrand and Schnabl 2006) have acknowledged that despite the official status of a freely floating economy the exchange rate has played an important role for Japanese monetary policy, in particular in times of appreciation. But to 
our knowledge no paper has formally analyzed the asymmetric impact of the exchange rate on Japanese interest rate decisions in appreciation phases and has explored the respective impact on the liquidity trap.

We want to trace the possibly changing impact of the yen/dollar exchange rate on Japanese monetary policy based on a rolling Taylor type monetary policy reaction function with an exchange rate term. This allows us to provide a dynamic picture of the role of the exchange rate for Japanese monetary policy. To make an assessment of the impact of the yen appreciation on Japan's liquidity trap we introduce an interaction term into the GMM framework.

\section{Model SPecificAtion}

To investigate the impact of the exchange rate on Japanese monetary policy in a freely floating environment we use the Taylor rule type forward-looking baseline specification by Clarida, Galí and Gertler (1998) and add an exchange rate term:

$$
i_{t}^{*}=\bar{i}+\beta\left(E\left[\pi_{t+12} \mid \Omega_{t}\right]-\pi^{*}\right)+\gamma\left(E\left[y_{t} \mid \Omega_{t}\right]-y_{t} *\right)+\delta\left(e_{t}-e_{t}^{*}\right)
$$

In equation (1) $i_{t} *$ is the central bank's target nominal interest rate at the time $\mathrm{t}$, which is assumed to depend on the long-term equilibrium interest rate $\bar{i}$, expected inflation $\pi_{\mathrm{t}+12}$, expected current output $y$ and (possibly) the current exchange rate $e_{\mathrm{t}}$. Equation (1) underlies the assumption that the current output is not known at the time of the interest decision, but the exchange rate $e_{t}$ is known with a minimum of information costs. We define the central bank targets other than the interest rate in gaps, i.e., as expected deviations from the (desired) bliss points for inflation $\left(\pi_{t}^{*}\right)$, output $\left(y_{t}{ }^{*}\right)$, and the exchange rate $\left(e_{t}{ }^{*}\right) . E$ is the expectation operator and $\Omega_{t}$ is the central bank's information set at the time $\mathrm{t}$.

If, for instance, within a one year time horizon expected inflation $\left(E\left[\pi_{t+12} \mid \Omega_{t}\right]\right)$ is rising above (falling under) the target level $\pi^{*}$, the central bank will raise (cut) the interest rate $i_{t}^{*}$. Similarly, the interest rate will be reduced (increased), if current output is under (above) the desired level $y_{t}{ }^{*}$.

The exchange rate may influence interest rate decisions for several reasons. Exchange rate changes affect inflation expectations and output, as well as decision making in international policy coordination (as outlined by Funabashi 1988 and Henning 1994). If the exchange is appreciating below (depreciating above) the level $e_{t}^{*}$ (in price notation), which is regarded as appropriate by the 
monetary authorities, interest rates will be reduced (increased). In this context the monetary authorities might be more concerned about appreciation than depreciation.

Following Clarida, Galí and Gertler (1998), we assume interest rate smoothing as it is practised by the large (independently floating) economies (US, UK, Euro Area, Japan before March 1999) to smooth out shocks in the money market ${ }^{1}$ :

$i_{t}=(1-\rho) i_{t} *+\rho i_{t-1}+v_{t}$

In equation (2) $i_{t}$ is the short-term nominal interest rate set by the central bank at the time $t$ which depends on the target interest rate $i_{t} *$ and the interest rate of the previous period. The coefficient $\rho$ captures the degree of interest smoothing. The error term $v_{t}$ is assumed to be normally distributed. Substituting equation (1) into (2), defining a constant $\alpha \equiv \bar{i}-\beta \pi^{*}$, and eliminating the unobserved forecast variables yields the final specification for the estimation given by

$i_{t}=(1-\rho) \alpha+(1-\rho) \beta \pi_{t+12}+(1-\rho) \gamma\left(y_{t}-y_{t} *\right)+(1-\rho) \delta\left(e_{t}-e_{t}^{*}\right)+\rho i_{t-1}+\varepsilon_{t}$

with $\varepsilon_{t}=-(1-\rho)\left(\beta\left(\pi_{t+12}-E\left[\pi_{t+12} \mid \Omega_{t}\right]\right)+\gamma\left(y_{t}-y_{t} *-E\left[y_{t}-y_{t} * \mid \Omega_{t}\right]\right)\right)+v_{t}$

as a linear combination of the unobserved forecast variables and the error term $v_{t}$.

\section{ESTIMATIONS}

We estimate equation (3) based on a GMM framework.

\section{Data and Observation Period}

We use monthly data from the IMF International Financial Statistics. Japanese short-term interest rates are the uncollateralized money market call rates (mutanpô kôru rêto). Since monthly data are not available for the real GDP, we use seasonally adjusted industrial production as a proxy. The Hodrick-Prescott filter is used to calculate the output gap. ${ }^{2}$ Inflation is measured as log differences of consumer price indices versus the previous years' month.

\footnotetext{
${ }^{1}$ China is already a large economy and can be expected to grow further. Therefore - in terms of size - it would qualify for a monetary policy as practiced in the US, UK, euro area and Japan (Goodfriend and Prasad 2007). Nevertheless, as long as financial markets remain underdeveloped, exchange rate stabilization is very likely to persist (McKinnon and Schnabl 2004).

${ }^{2}$ Different ways of estimating the output gap yield by and large the same results.
} 
Figure 1: Yen/Dollar Exchange Rate and Interest Rate in Japan and US 1971-1999
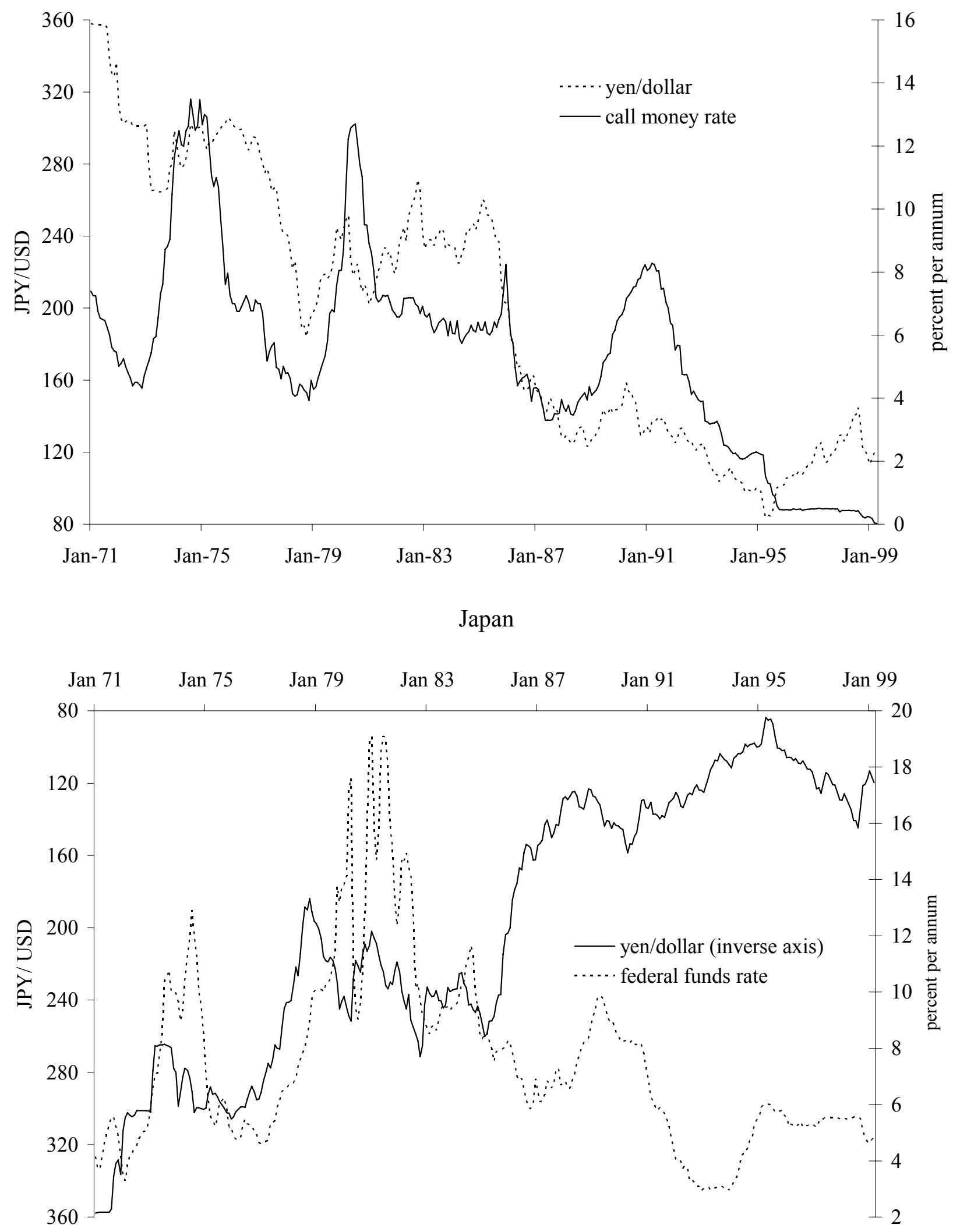

Source: IMF: IFS.

US 
The yen/dollar gap is the deviation of the nominal yen/dollar exchange rate from a five-year (60 months) backwards moving average. We justify the moving average as a reference value for the calculation of the exchange rate gap - rather than an arithmetic average - by the fact that since the early 1970s the yen appreciated considerably against the dollar (upper panel of Figure 1). Therefore the notion by which an exchange rate was considered as "high" changed over time. If the Chinese yuan would be allowed to float we would expect a similar situation because during the economic catch-up the Balassa-Samuleson effect would lead to a persistent nominal appreciation reflecting relative productivity gains (De Grauwe and Schnabl 2005).

The Augmented Dickey-Fuller test rejects the null hypothesis for the output gap and the exchange rate gap at the $1 \%$-level, and for inflation at the $10 \%$-level. For the short-term interest rate the null cannot be rejected at the 10\%-level. Following Clarida, Galí and Gertler (1998) we interpret this low acceptance as a result of the low power of the test. The observation period is from 1974:01, when the Japanese yen can be assumed to have become fully flexible up to 1999:03 when the Japanese short-term interest rate reached the zero bound and could therefore no longer be used as an instrument for monetary policy making.

\section{Estimation Framework}

The Generalized Method of Moments (GMM) provides a framework to cope with possible endogeneity bias between the interest rate and the independent variables (inflation, output and exchange rate). We use a "two-step" GMM with Newey-West standard errors. The lags of the regressors up to twelve previous periods and a constant are used as instruments. ${ }^{3}$

The estimation proceeds in three steps. First, we estimate global (static) coefficients for the entire observation period from 1974:01 to $1999: 03$ as well as for shorter observation periods as a robustness check. Second, we estimate ten-year rolling windows starting in 1974:01 and iterating forward month by month until 1999:03 in order to create a continuous picture on the role of the exchange rate for Japanese monetary policy in different time periods. Third, we introduce an interaction term which captures a possible asymmetric behaviour of the Bank of Japan monetary policy with respect to yen appreciation or depreciation (section IV). As an additional sensitivity test we perform the three steps also for the Federal Reserve which is widely argued to show "benign neglect" with respect to the exchange rate, in particular for the period after 1985. For instance, as

\footnotetext{
${ }^{3}$ We tested different sets of instruments by excluding/adding lags of the explanatory variables. The results remain widely unchanged.
} 
shown in the lower panel of Figure 1, there is no straightforward relationship between the exchange rate and the federal funds rate.

\section{Static Results}

We estimate equation 3 for three alternative observation periods. (1) The whole observation period ranging from the end of the Bretton-Woods System until Japan's fall into the liquidity trap in March $1999^{4}$, (2) the observation period of Clarida, Galí and Gertler (1998) from April 1979 to December 1994 and (3) a period from April 1979 to March 1999 which excludes the period up to 1978 as by Clarida, Galí and Gertler (1998). ${ }^{5}$

We are primarily interested in the question of how the exchange rate affected the Bank of Japan's interest rate setting. Based on former studies such as those of McKinnon and Ohno (1997) and McKinnon and Schnabl (2004), we would expect a positive $\delta$ coefficient for two reasons. First, as appreciations affect the competitiveness of exports negatively, the Bank of Japan may have tended to lower interest rates to soften the yen appreciation and thereby to sustain growth. Second, as Japan's very high international assets are mostly denominated in US dollars, yen appreciations against the dollar lower the worth of these assets in terms of domestic currency, for instance in the balance sheets of financial institutions. Interest rate cuts in times of appreciation enhance financial stability and are therefore in the interest of both the export and the financial sector. Both characteristics also apply to China.

The results of the static estimations for the Bank of Japan are reported in Table 1. They are mainly in line with Clarida, Galí and Gertler (1998) revealing a significant impact of output, inflation and the exchange rate on Japanese monetary policy. In specific the $\delta$ coefficients have the expected signs and are highly significant for all observation periods providing robust evidence for a strong impact of the exchange rate on Japanese monetary policy. Interest rates were cut (increased) in appreciation (depreciation) phases. This is in line with previous research as listed in section I. For the whole observation period from 1974:01 up to 1999:03 the coefficient $\delta$ is positive and significant at the $5 \%$-level. The size of the $\delta$-coefficient suggests that an appreciation (depreciation) of the Japanese yen by 10 yen below (above) the target value led ceteris paribus to an interest rate cut (increase) by 0.83 percentage points.

\footnotetext{
${ }^{4}$ After March 1999 the interest rate remained at zero and could not be used anymore as a monetary policy instrument.

${ }^{5}$ Clarida, Galí and Gertler (1998: 1034) exclude the pre-1979 period because they argue that monetary policies were out of control during this period and therefore the estimations were unstable.
} 
The result for the observation period of Clarida, Galí and Gertler (1998) from 1979:04 to 1994:12 is similar. The exchange rate term is significant at the $1 \%$-level and the size of the coefficient is even larger suggesting that during this shorter period interest rates were cut (increased) by 1.2 percentage points in reaction to an appreciation (depreciation) by 10 yen per dollar below (above) the target value. For the observation period from April 1979 to March 1999 the impact of the exchange rate on the interest rate is even stronger (1.7 percentage points interest rate cut (increase) in response to an appreciation (depreciation) by 10 yen per dollar below (above) the target value). The coefficients which measure the impact of output and inflation on Japanese interest rate decisions have the expected positive signs and are highly significant for all observation periods.

Table 1: GMM Estimations of Equation 3 for the Bank of Japan

\begin{tabular}{clllll} 
& \multicolumn{5}{c}{ Coefficients } \\
\cline { 2 - 6 } Sample & $\alpha$ & $\beta$ & $\gamma$ & $\delta$ & $\rho$ \\
\hline 1974:01-1999:03 & 0.003806 & $1.308869^{* * *}$ & $0.758157^{* *}$ & $0.000832^{* *}$ & $0.976032^{* * *}$ \\
& $(0.009999)$ & $(0.269450)$ & $(0.312840)$ & $(0.000416)$ & $(0.008332)$ \\
\hline 1979:04-1994:12 & $0.022443 * * *$ & $1.547003^{* * *}$ & $0.634762^{* * *}$ & $0.001226 * * *$ & $0.943432 * * *$ \\
& $(0.004846)$ & $(0.215876)$ & $(0.186282)$ & $(000281)$ & $(0.008838)$ \\
\hline $1979: 04-1999: 03$ & 0.002342 & $2.246797 * * *$ & $0.699022^{* * *}$ & $0.001659 * * *$ & $0.961037 * * *$ \\
& $(0.006782)$ & $(0.007872)$ & $(0.333956)$ & $(0.15928)$ & $(0.000319)$ \\
\hline
\end{tabular}

Standard errors in parentheses. $* * *, * *, *$ denotes significance at $1 \%, 5 \%$, and $10 \%-$ level. Test for over-identifying restrictions: J-Statistic for global estimates from 1974:01 to 1999:03: $\mathrm{J}=$ $0.060190, \chi^{2}(28), \mathrm{p}$-value $=0.92 . \mathrm{J}$-Statistic for sub-period from 1979:04 to 1994:12: $\mathrm{J}=0.103027$, $\chi^{2}(28), \mathrm{p}$-value $=0.88 . \mathrm{J}$-Statistic for sub-period from 1979:04 to 1999:03: $\mathrm{J}=0.100958, \chi^{2}(28), \mathrm{p}$ value $=0.66$.

In contrast, as shown in Table 2 for the Federal Reserve there is weak evidence that the exchange rate had a recognizable impact on US interest rate decisions. The result is similar to the Bank of Japan for the whole observation period, as the exchange rate term is negative ${ }^{6}$ and turns out significant at the $5 \%$ level. Yet, the exchange rate term $\delta$ is significantly smaller than for Japan and is insignificant for the other two observation periods. The coefficients which show the impact of output and inflation on the Federal Reserves' monetary policy have the expected signs and are highly significant.

To this end, the static estimations suggest that - in contrast to the Federal Reserve - the Bank of Japan pursued with one instrument (interest rate) three targets (inflation, output, exchange rate). This may imply conflicts between the single targets such as between the exchange rate and inflation. For instance when interest rates are reduced (money supply expanded) to counteract appreciation, this may in the longer-term contradict the inflation target. Indeed, in the case the

\footnotetext{
${ }^{6}$ A dollar appreciation (positive sign) implies a lower interest rate.
} 
Japanese bubble economy the substantial interest rate cuts in 1986 and 1987 which intended to stop the "excessive" post-Plaza yen appreciation increased the liquidity supply to the Japanese economy which fuelled the speculation in the Japanese real estate and stock markets (Hoffmann and Schnabl 2007).

Table 2: GMM Estimations of Equation 3 for the Federal Reserve

\begin{tabular}{clllll} 
& \multicolumn{5}{c}{ Coefficients } \\
\cline { 2 - 6 } Sample & $\alpha$ & $\beta$ & $\gamma$ & $\delta$ & $\rho$ \\
\hline 1974:01-1999:03 & 0.017625 & $1.173998^{* * *}$ & $0.618517 * *$ & $-0.00102 * *$ & $0.958138^{* * *}$ \\
& $(0.014452)$ & $(0.354942)$ & $(0.24071)$ & $(0.000477)$ & $(0.009509)$ \\
\hline 1979:04-1994:12 & 0.009898 & $1.581558^{* * *}$ & $0.681932 * * *$ & -0.0002 & $0.943386^{* * *}$ \\
& 0.015525 & $(0.35457)$ & $(0.195969)$ & $(0.000425)$ & $(0.011862)$ \\
\hline 1979:04-1999:03 & 0.010712 & $1.609592^{* * *}$ & $0.657147 * * *$ & -0.0000953 & $0.936188^{* * *}$ \\
& $(0.01166)$ & $(0.305563)$ & $(0.17887)$ & $(0.000355)$ & $(0.013081)$ \\
\hline
\end{tabular}

Standard errors in parentheses. $* * *, * *, *$ denotes significance at $1 \%, 5 \%$, and $10 \%-$ level. Test for over-identifying restrictions: J-Statistic for global estimates from 1974:01 to 1999:03: $\mathrm{J}=$ $0.093189, \chi^{2}(28), \mathrm{p}$-value $=0.84 . \mathrm{J}$-Statistic for sub-period from 1979:04 to 1994:12: $\mathrm{J}=0.122518$, $\chi 2(28), \mathrm{p}$-value $=0.93$. J-Statistic for sub-period from 1979:04 to 1999:03: $\mathrm{J}=0.071316, \chi 2(28), \mathrm{p}$ value $=0.95$

\section{Dynamic Results}

The static estimations don't provide information about a possibly changing impact of the exchange rate on Japanese (or US) monetary policy decision making over the time dimension, in particular in times of appreciation. The impact of the exchange rate on Japanese monetary policy may have been weak during the 1970s, but may have become stronger during the 1980s and 1990s. Interest rates may have declined when the yen appreciated (falling exchange rate in price notation) but may have remained unchanged when the yen depreciated. This is suggested by the upper panel of Figure 1 which shows the development of the yen/dollar exchange rate and the Japanese call money rate. Periods of strong appreciation such as 1977/78, 1986/87 and the first half of the 1990s are associated with substantial interest rate cuts. In contrast, in periods of yen depreciation such as during the first half of the 1980s and between 1996 and 1998, interest rates remained widely unchanged.

To identify a changing impact of the yen/dollar exchange rate on monetary policy making, we pursue a dynamic approach to the monetary policy reaction function by rolling $\delta$ coefficients. If the Bank of Japan had operated under the same (stable) regime throughout the whole observation 
period, we would expect similar coefficients and standard errors. Otherwise, the overlapping subsamples should reveal regime shifts.

When estimating rolling $\delta$ coefficients for equation (3) we face a trade off with respect to the window size. The robustness of the results is increasing with the sample size due to the limited finite sample properties of the GMM. To detect potential changes in the monetary policy regime we prefer small sample sizes which can be assumed to be more sensible to possible regime shifts. Based on various tests we see a window size of 120 observations (10 years) as an adequate compromise. Other window sizes yield by and large the same results.

The respective first sub-sample which is from 1964:01 up to 1974:01 extends to the Bretton Woods system. We are aware of the fact that during the first few years of the rolling estimations Japanese monetary policy decision making is not adequately specified, as a fixed exchange rate regime constitutes a different monetary framework than modelled in equation (3) with the exchange rate being the prominent monetary policy target. ${ }^{7}$ This bias declines as the window is shifted month by month.

Figure 2 shows the t-statistics for the exchange rate term ( $\delta$ coefficient) for the Bank of Japan (upper panel) and the Federal Reserve (lower panel). We focus on the t-statistics of the exchange rate term as they indicate if the exchange rate had a significant impact on monetary policy decisions while at the same time controlling for the impact of output and inflation on interest rates. The rolling coefficients and t-statistics for output, inflation and the exchange rate are reported in the appendix in Figure 3 for the Bank of Japan and Figure 4 for the Federal Reserve. The solid horizontal grey lines indicate the significance levels of the $\delta$ coefficients at the $5 \%$ level.

The upper panel of Figure 2 and the lower panels of Figure 3 show the t-statistics for the $\delta$ coefficient and the size of the $\delta$ coefficient estimated by the Bank of Japan monetary policy reaction function. For the Bank of Japan the $\delta$ coefficients are as expected mostly positive reflecting interest rate cuts (increases) in times of appreciation (depreciation). The importance of the yen/dollar exchange rate on Japanese monetary policy seems to have changed over time. Up to the late 1970s the significance level is comparatively low and therefore the evidence that the exchange rate had a significant impact on the Japanese monetary policy is weak. Yet, during the appreciation phase in the years 1977 into 1979 there is a sharp increase in the significance level, which is also in line with attempts of international policy coordination to stop the dollar depreciation (Henning 1994).

\footnotetext{
${ }^{7}$ Indeed the rolling results as shown in Figure 3 and Figure 4 show that the coefficients of inflation and output turn out insignificant and negative in the first ten years of the reporting period.
} 
Figure 2: Rolling GMM T-Statistics for Exchange Rate Gap ( $\delta$ Coefficient)

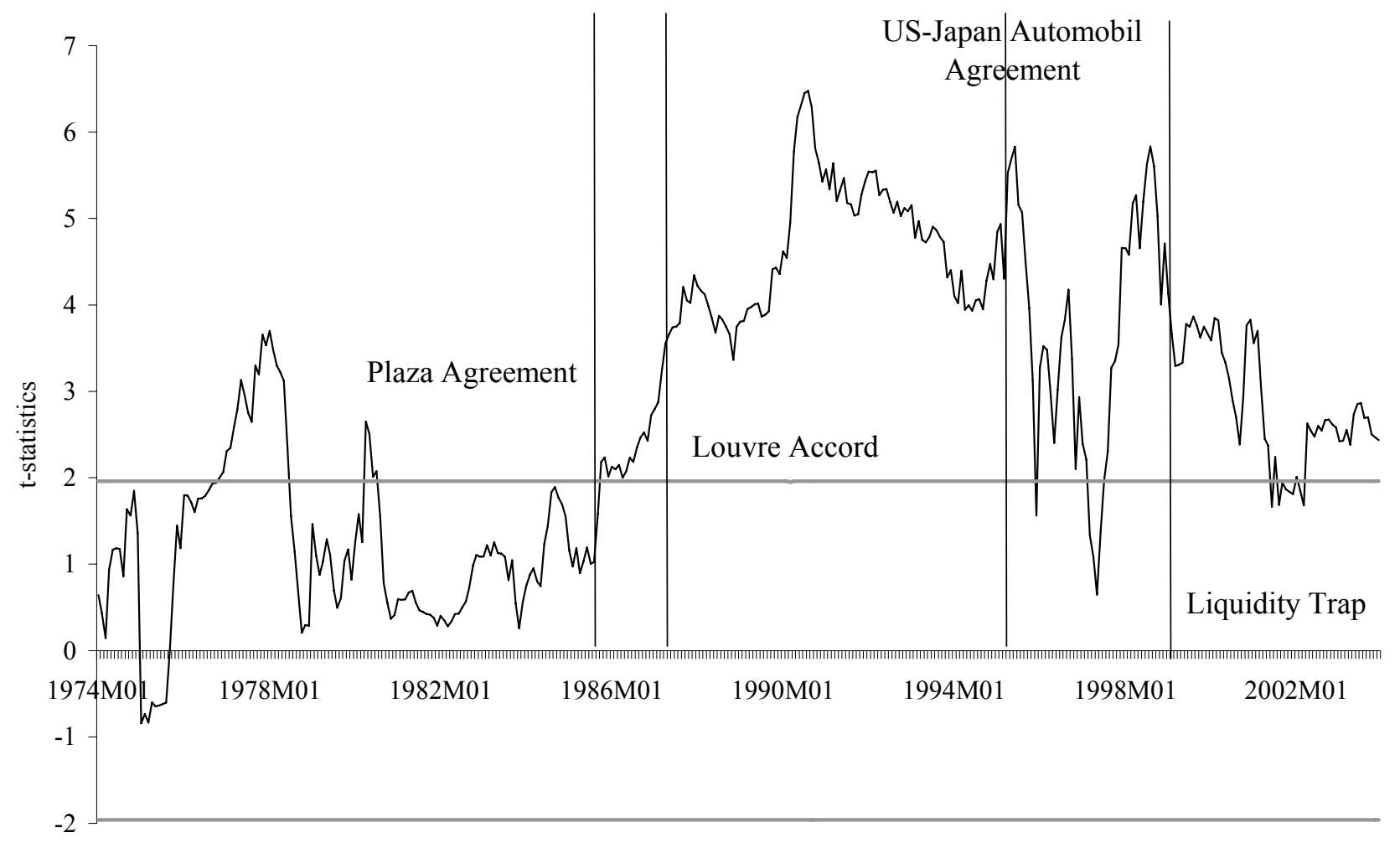

Bank of Japan

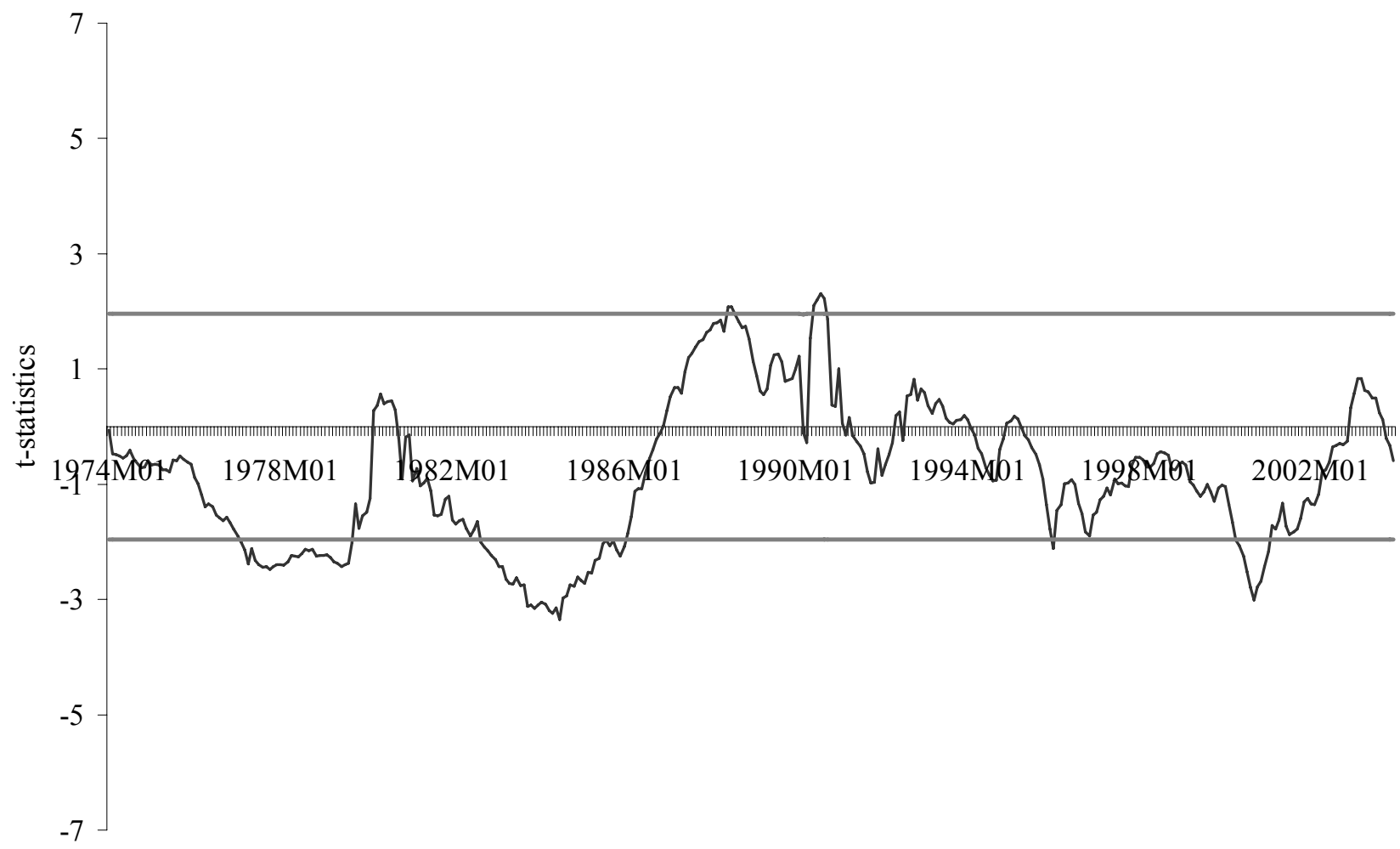

Federal Reserve

Note: Dark lines are the t-statistics of the rolling coefficients. Solid grey lines indicate 5\%-level of significance. Values are plotted for the last period of the estimated sub-sample. 
From the early 1980s up to 1985, the yen remained weak against the dollar and Japanese monetary policy decisions do not seem to have been significantly affected by exchange rate changes. The September 1985 Plaza Agreement intended to appreciate the yen against the dollar by joint international (sterilized) foreign exchange intervention and the Japanese yen started to appreciate strongly (Funabashi 1988). In the first months after the Plaza Agreement there is only weak evidence for an significant impact of the exchange rate on Japan's monetary policy, but after a certain time lag - as shown by Figure 2 and Figure 3 - both, the size and the significance level of the $\delta$ coefficient increase sharply showing attempts of the Japanese central bank to counteract appreciation pressure by interest rate cuts.

With the February 1986 Louvre Agreement, officially monetary (and fiscal) policy action was taken to prevent the yen from appreciating further (Funabashi 1988, Esaka 2000). Japanese interest rate cuts are reflected in further increasing significance levels of the $\delta$ coefficients. The value of the $\delta$ coefficient rises over the 1974-1999 average. The strong impact of the exchange rate on Japanese monetary policy continues throughout the second half of the 1980s and only declines after the burst of the bubble economy in late 1989.

A declining value of the exchange rate coefficient (while still remaining highly significant) during the early 1990s indicates that the Bank of Japan gave less weight to the exchange rate. Nevertheless the impact of the exchange rate on the BOJ interest rate decisions remains significant during the 1990s when the yen continued to appreciate and the ailing (domestic) Japanese economy became even more dependent on exports. A new highly significant spike in the $\delta$-coefficient is observed in 1995, when the Bank of Japan further lowered interest rates to stop the rise of the yen up to its record high of less than 80 yen per dollar during the US-Japanese automobile conflict (McKinnon and Ohno 1997). ${ }^{8}$

While both, the size and the significance level of the $\delta$ coefficient decline after 1995 when the yen depreciated considerably against the dollar (Figure 1) a new spike is observed in 1998 until repeated attempts to prevent the yen from appreciating and stimulating the ailing Japanese economy by interest rate cuts brought Japan into the liquidity trap in March 1999. All in all, the upper panel of Figure 2 suggests that the impact of the yen/dollar exchange rate changed over time with respect to two dimensions. First, the impact seems to be much stronger in the post-Plaza period compared to the pre-Plaza period. Second, it seems that the impact of the exchange rate on interest rate decisions was stronger in appreciation than in depreciation phases.

\footnotetext{
${ }^{8}$ McKinnon and Ohno (1997) argue that the US put pressure on Japan in context of the negotiations about Japanese automobile exports to the US by bringing the dollar under depreciation pressure. The conflict was settled in February 1995 when Japan agreed to voluntary export restraints and the US announced a strong dollar policy.
} 
In comparison to the Bank of Japan the response of the Federal Reserve to exchange rate swings is weak as shown by the lower panels of Figure 2 and Figure 4 in the appendix. The t-statistics as shown Figure 2 remain mostly within the band of the 5\% significance level reflecting the widely acknowledged "benign neglect" of the Federal Reserve towards the exchange rate. The possible reaction pattern of the Federal Reserve towards exchange rate changes remains uncertain as - in contrast to the Bank of Japan - the t-values show both positive and negative signs. The upshot is that there is no evidence in favour of a systematic impact of the exchange rate on the Federal Reserves' monetary policy decisions in particular since the mid 1980s. In contrast as shown in Figure 4 inflation and output turn out highly significant showing - as expected - the dominant role of inflation and output for the Federal Reserves' monetary policy making.

The - in contrast to the Federal Reserve - changing impact of the exchange rate for the Bank of Japans' monetary policy decisions implies not only a conflict between the inflation and exchange rate target as argued above but rising uncertainty for private agents because the central bank tends to "switch" between the inflation and the exchange rate target. An example for this time inconsistency in monetary policy is the period around the bubble economy. After the Plaza Agreement, interest rates were reduced by more than 5 percentage points to counteract the yen appreciation in 1986 and 1987.

After the increased money supply had contributed to excessive speculation in the Japanese stocks and real estate markets, the Bank of Japan increased the interest rate sharply (again by more than 5 percentage points) in 1989 and 1990 to counteract the inflationary pressure of the bubble (Figure 1). When the yen started to appreciate after the burst of the bubble, interest rates were cut sharply again to counteract the continuing appreciation. The short-term interest rate gradually approached the zero bound.

\section{ASYMMETRIC BEHAVIOUR AND LIQUIDITY TRAP}

The estimations as performed in section III suggest that the Bank of Japan responded actively to exchange rate changes. While the static estimations as reported in Table 1 provide evidence that the exchange rate in general has played an important role for Japanese monetary policy making, the rolling estimations show that the Bank of Japan was more sensible to exchange rate changes after the Plaza Agreement. Although the rolling t-statistics of the $\delta$ coefficient suggest higher significance levels in appreciation phases they do not provide systematic evidence for an asymmetric reaction of Japanese interest rates in response to yen appreciation. In principle a 
positive $\delta$ coefficient indicates both interest cuts in times of appreciation and interest rate hikes in times of depreciation.

Possible asymmetric monetary policy behaviour with respect to exchange rate changes in appreciation and depreciation phases may provide an explanation why Japan fell into the liquidity trap in early 1999 as suggested by McKinnon and Ohno (1997). Given that appreciation and depreciation phases are equally distributed over the observation period, interest rates would tend to move ceteris paribus towards zero if interest rates are reduced when the exchange rate appreciates but remain widely unchanged when the exchange rate depreciates. If - as in the case of Japan and in general in the case of countries in the economic catch-up process such as China (McKinnon and Schnabl 2006, De Grauwe and Schnabl 2005) - appreciation phases are more frequent than depreciation phases, this effect would be enforced.

We introduce an asymmetric interaction term as proposed for instance by Zakoian (1994) for GARCH frameworks into equation 3 to isolate the Bank of Japan monetary policy response in appreciation phases. This interaction term I takes the value 1 for appreciation periods $\left(\mathrm{e}^{*}>\mathrm{e}_{\mathrm{t}}\right)$ and the value 0 for depreciation periods $\left(\mathrm{e}^{*}<\mathrm{e}_{\mathrm{t}}\right)$. To identify an asymmetric behaviour in interest rate decisions with respect to appreciation phases the interaction term is multiplied with the exchange rate gap. This yields the following specification:

$i_{t}=(1-\rho) \alpha+(1-\rho) \beta \pi_{t+12}+(1-\rho) \gamma\left(y_{t}-y_{t}^{*}\right)+(1-\rho)\left(\varphi+\eta I_{t}\right)\left(e_{t}-e_{t}^{*}\right)+\rho i_{t-1}+\varepsilon_{t}$

In equation 4 the coefficient $\eta$ captures the interest rate responses in appreciation phases. If $\eta$ is significant (and positive) the Bank of Japan reacted significantly different in appreciation phases compared to depreciation phases (with interest rate cuts). The size of the $\eta$ coefficient (economic effect) indicates the interest rate effect which is additionally triggered by the appreciation. The total economic effect in appreciation phases is captured by the sum of the coefficients $\eta$ and $\varphi$. The Wald test for joint significance of $\eta$ and $\varphi$ indicates of this total effect is significant.

The results for the Bank of Japan are reported in Table 3 for three different observations periods and provide evidence for an asymmetric reaction of Japanese monetary policy to exchange rate changes only in appreciation phases. For the whole observation period from January 1974 to March 1999 the $\eta$ coefficient is significant at the ten percent level. In appreciation phases the Bank of Japan responded ceteris paribus to an appreciation of 10 yen per dollar below the target value with a 10 percentage points interest rates cut in appreciation phases. The $\varphi$ and $\eta$ coefficients are jointly significant at the 10 percent level as indicated by the Wald test. 


\section{Table 3: GMM Estimations of Equation 4 Accounting for Appreciation Phases with Interaction Terms for the Bank of Japan}

\begin{tabular}{|c|c|c|c|c|c|c|}
\hline \multirow[b]{2}{*}{ Sample } & \multicolumn{5}{|c|}{ Coefficients } & \multirow[b]{2}{*}{$\rho$} \\
\hline & $\alpha$ & $\beta$ & $\gamma$ & $\Phi$ & $\eta$ & \\
\hline \multirow{4}{*}{$\begin{array}{l}1974: 01- \\
1999: 03\end{array}$} & 0.111467 & $1.649323 * * *$ & $1.104812^{*}$ & $-0.007854^{*}$ & $0.017889^{*}$ & $0.97411^{* * *}$ \\
\hline & $(0.057709)$ & $(0.561440)$ & $(0.723082)$ & $(0.004984)$ & $(0.011229)$ & $(0.015613)$ \\
\hline & & & & & $\chi^{2(1)}$ & p-value \\
\hline & Wald-Test of & Joint Significa & ice of $\boldsymbol{\eta}$ and $\boldsymbol{\varphi}$ & & $3.26174^{*}$ & 0.07 \\
\hline \multirow{4}{*}{$\begin{array}{l}\text { 1979:04- } \\
\text { 1994:12 }\end{array}$} & $0.039938 * * *$ & $1.48243 * * *$ & $0.540838 * * *$ & 0.000134 & $0.002725 * *$ & $0.936912 * * *$ \\
\hline & $(0.008765)$ & $(0.230780)$ & $(0.164379)$ & $(0.000444)$ & $(0.001129)$ & $(0.009302)$ \\
\hline & & & & & $\chi 2(1)$ & $p$-value \\
\hline & Wald-Test of & Joint Significal & ice of $\boldsymbol{\eta}$ and $\boldsymbol{\varphi}$ & & $39.7990 * * *$ & 0.0000 \\
\hline \multirow{4}{*}{$\begin{array}{l}\text { 1979:04- } \\
\text { 1999:03 }\end{array}$} & $0.026613 * *$ & $2.374956^{* * *}$ & $0.693892 * * *$ & -0.000162 & $0.004811 * * *$ & $0.961944 * * *$ \\
\hline & $(0.011616)$ & $(0.38123)$ & $(0.177357)$ & $(0.00062)$ & $(0.001651)$ & $(0.007694)$ \\
\hline & & & & & $\chi^{2(1)}$ & p-value \\
\hline & Wald-Test of & Ioint Significar & ice of $\boldsymbol{\eta}$ and $\varphi$ & & $22.1963^{* * *}$ & 0.0000 \\
\hline
\end{tabular}

Standard errors in parentheses. $* * *, * *, *$ denotes significance at $1 \%, 5 \%$, and $10 \%-$ level. Test for over-identifying restrictions: J-Statistic for global estimates from 1974:01 to 1999:03. J = $0.049310, \chi^{2}(27), p$-value $=0.97$. J-Statistic for sub-period from 1979:12 to 1994:12. J $=0.101262$, $\chi 2(27), \mathrm{p}$-value $=0.86 . \mathrm{J}$-Statistic for sub-period from 1979:12 to 1994:12: $\mathrm{J}=0.101262, \chi 2(27)$, $\mathrm{p}$-value $=0.86 . \mathrm{J}$-Statistic for sub-period from 1979:12 to 1999:03: $\mathrm{J}=0.090935, \chi 2(27), \mathrm{p}$-value $=$ 0.74. $\eta$ represents the coefficient of the interaction term of the yen/dollar gap and the appreciation dummy. The dummy variable is 1 in appreciation phases and 0 for depreciation phases.

The evidence for an asymmetric impact of the exchange rate on Japanese interest rates in appreciation phases is getting stronger for the observation periods which start in 1979. Remember that the significance levels of the rolling $\delta$ coefficients increased after 1985. For the observation period from April 1979 to December 1994 the $\eta$ coefficient is as expected positive and turns out highly significant indicating an asymmetric response of the Japanese monetary policy to exchange rate changes in appreciation phases. Now the economic effect is smaller, as $\varphi$ plus $\eta$ indicate an interest rate cut by 2.8 percentage points in response to an appreciation of 10 yen per dollar below the target value. The Wald test indicates that the total economic effect in appreciation phases is highly significant at the one percent level.

Also for the observation period from April 1979 to March 1999 there is strong evidence that Japanese monetary policy reacted strongly to the appreciation pressure on the Japanese yen. The $\eta$ is highly significant, but the economic effect is smaller, as the Bank of Japan seems to have cut interest rates by 0.46 percentage points in reaction to an appreciation of 10 yen per dollar below the target value. Again $\eta$ and $\varphi$ are together highly significant. This implies strong evidence in favour of an asymmetric response of the Bank of Japan in appreciation phases. In short, the continuous appreciation pressure on the Japanese yen and Japan's "fear of appreciation" gradually pushed the country into the liquidity trap. 
Equation 4 is also estimated for the Federal Reserve. The results are reported in Table 4. In the case of the Federal Reserve for all three observation periods, an asymmetric interest rate effect originating in appreciation phases can not be isolated. The $\eta$ coefficient remains for all three observation periods insignificant. To this end the GMM estimation of equation 4 which accounts for possible asymmetric behaviour in appreciation phases with an interaction term, clearly confirms the Federal Reserves' benign neglect towards the exchange rate.

\section{Table 4: GMM Estimations of Equation 4 Accounting for Appreciation Phases with Interaction Terms for the Federal Reserve}

\begin{tabular}{|c|c|c|c|c|c|c|}
\hline \multirow[b]{2}{*}{ Sample } & \multicolumn{6}{|c|}{ Coefficients } \\
\hline & $\alpha$ & $\beta$ & $\gamma$ & $\varphi$ & $\eta$ & $\rho$ \\
\hline \multirow{4}{*}{ 1999:03 } & 0.012429 & $1.131625 * *$ & $0.604064 * *$ & -0.001686 & 0.001139 & $0.95782 * * *$ \\
\hline & $(0.022727)$ & $(0.569118)$ & $(0.257906)$ & $(0.002333)$ & $(0.003944)$ & $(0.0107)$ \\
\hline & & & & & $\chi^{2(1)}$ & p-value \\
\hline & Wald-Test & Joint Significa & ace of $\boldsymbol{\eta}$ and $\varphi$ : & & $3.8547^{*}$ & 0.05813 \\
\hline \multirow{4}{*}{$\begin{array}{l}1979: 04- \\
1994: 12\end{array}$} & 0.005368 & $1.581152 * * *$ & $0.647058 * * *$ & -0.000743 & 0.000792 & $0.94236 * * *$ \\
\hline & $(0.019705)$ & $(0.424957)$ & $(0.221897)$ & $(0.002007)$ & $(0.003339)$ & $(0.016493)$ \\
\hline & & & & & $\chi 2(1)$ & $p$-value \\
\hline & Wald-Test & Joint Significa & ace of $\boldsymbol{\eta}$ and $\boldsymbol{\varphi}$ : & & 0.75330 & 0.38540 \\
\hline \multirow{4}{*}{$\begin{array}{l}\text { 1979:04- } \\
1999: 03\end{array}$} & 0.008144 & $1.593686 * * *$ & $0.664951 * * *$ & -0.0004 & 0.00059 & $0.935083 * * *$ \\
\hline & $(0.014829)$ & $(0.345569)$ & $(0.183452)$ & $(0.00164)$ & $(0.002743)$ & $(0.016553)$ \\
\hline & & & & & $\chi 2(1)$ & $p$-value \\
\hline & Wald-Test & Joint Significa & ace of $\boldsymbol{\eta}$ and $\boldsymbol{\varphi}$ : & & 0.1365 & 0.7118 \\
\hline
\end{tabular}

All in all, the interaction term provides strong evidence that (starting from the late 1970s) the Bank Japan responded asymmetrically to exchange rate swings in appreciation phases. This implies that the Bank of Japans monetary policy contributed to Japans fall into the liquidity trap for two reasons. First, interest rates were reduced in times of appreciation, but remained widely unchanged in times of depreciation. Second, during the economic catch-up of the Japanese economy which can be assumed to have lasted up to the late 1980s, appreciation phases were more frequent than depreciation phases due to relative productivity gains with respect to the US.

This finding is line with McKinnon and Schnabl (2006) who argue that the flexible exchange rate of the yen against the dollar has contributed to a negative risk premium on the Japanese interest rate which - given the US interest rates and sustained appreciation expectations for the Japanese yen pushed Japan into the liquidity trap. 


\section{ECONOMIC POLICY IMPLICATION}

China faces today a similar decision like Japan faced in the early 1970s, i.e. a possible shift from a fixed to flexible exchange rate regime during the economic catch-up. The decision in July 2005 to release the hard peg to the dollar and to allow for a gradual but controlled appreciation of the Chinese yuan against the dollar can be seen as a first step into this direction. We studied for Japan the static and dynamic information content of Taylor-type monetary policy reaction functions with respect to the exchange rate. The Bank of Japan provides a suitable case study for China, as in both countries growth has been strongly dependent on exports. In addition both countries have large dollar denominated international assets. Both factors make the two countries one-sided sensible to appreciations of the domestic currency.

The static GMM estimations suggest that the Bank of Japan - although officially labelled a freely floating economy - pursued three targets of monetary policy making (inflation, output, exchange rate). This implies potential conflicts between single targets such as between the exchange rate and inflation as well as higher uncertainty with respect to monetary policy making - for instance as experienced during the Japanese bubble economy. Rolling GMM estimations provide evidence that the role of the exchange rate for the Bank of Japan's interest rate decisions has increased in times of strong appreciation pressure and was stronger after 1985 than before 1985. This confirms rising uncertainty with respect to monetary policy making as the central bank tended to "switch" between the exchange rate and the inflation target. Finally, an interaction term provides evidence in favour of a one sided sensibility of the Bank of Japan with respect to appreciation pressure. This suggests that repeated interest rate cuts have contributed to Japans liquidity trap.

To this end, our exercise provides the following lessons for China. First, even in the absence of (systematic) foreign exchange intervention the exchange rate might strongly influence monetary policy decision making under freely floating exchange rates which increases uncertainly, volatility and the probability of crisis. This effect will be particularly strong if the respective economy is sensible to the competitiveness of exports and if international assets are denominated in foreign currency.

As both seem to be the case for Japan and China, China might react similarly to (productivity driven) appreciation pressure once the exchange is floated. This would also imply a higher probability to fall into the liquidity trap. The economic policy implication is to maintain the fixed exchange rate regime as long as the economic catch-up of China continues and China remains sensible to exchange rate fluctuations, in specific in times of appreciation. While the dollar might be 
considered as the natural anchor currency for China, alternative anchors may be considered, if inflationary pressure is imported via the exchange rate peg.

\section{REFERENCES}

Cheung, Y., Chinn, M and FujII, E. 2005, Why the Renminbi Might be Overvalued (But Probably Isn't). Mimeo.

Chinn, M. and Dooley, M. (1998), Monetary Policy in Japan, Germany and the United States: Does One Size Fit All? In: Freedman, Craig (ed.): Japanese Economic Policy Reconsidered, Cheltenham, pp. 179-218.

Clarida, R., Galí, J. and Gertler, M. (1998), Monetary Policy Rules in Practice -Some International Evidence. European Economic Review, 42, pp. 1033-1067.

Cline, W. (2005), The Case for a New Plaza Agreement. Institute for International Economics, Policy Briefs 05-4.

De Grauwe, P. and Schnabl, G. (2005), Nominal versus Real Convergence with Respect to EMU Accession - EMU Entry Scenarios for the New Member States. Kyklos 58, 4, pp. 481-499.

EsAKA, T. (2000), The Louvre Accord and Central Bank Intervention: Was there a Target Zone? Japan and the World Economy 12, 2, pp. 107-126.

Frankel, J. 2006: On the Yuan. The Choice between Adjustment under a Fixed Exchange Rate and a Flexible Exchange Rate. CESifo Studies 52 (2006), 2, 246-275.

FUNABASHI, Y. (1988), Managing the Dollar: from Plaza to Louvre, Washington DC.

GoOdFriend, M. and PrasAd, E. (2007), A Framework for Independent Monetary Policy in China. CESifo Economic Studies 53, 1, pp. 2-41.

Goldstein, M. (2003): China's Exchange Rate Regime. Testimony before the Subcommittee on Domestic and International Monetary Policy, Trade, and Technology Committee on Financial Services. US House of Representatives.

HenNing, R. (1994), Currencies and Politics in the United States, Germany, and Japan. Washington D.C.

Hillebrand, ERIC / SchNABL, G. 2006: A Structural Break in the Effects of Japanese Foreign Exchange Intervention on Yen/Dollar Exchange Rate Volatility. European Central Bank Working Paper 650.

HoffmanN, A. / SchnABL, G. 2007: Geldpolitik, vagabundierende Liquidität und platzende Blasen in den neuen und Aufstrebenden Märkten. Wirtschaftsdienst 87, 4, 220-224.

Hutchison, M. (1988), Monetary Control with an Exchange Rate Objective: The Bank of Japan, 1973-86, Journal of International Money and Finance, 7, pp. 261-271. 
McKinnon, R. (2004), The East Asian Dollar Standard. China Economic Review 15, 3, 325-330.

McKinnon, R. (2007), Why China Should Keep its Dollar Peg. Forthcoming in International Finance 10.

McKinnon, R. and OHnO, K. (1997), Dollar and Yen: Resolving the Economic Conflict between the United States and Japan, MIT University Press.

McKinnon, R. and Schnabl, G. (2004), A Return to Soft Dollar Pegging in East Asia? Mitigating Conflicted Virtue. International Finance 7, 2, 169-201.

McKinnon, R. and Schnabl, G. (2006), China's Exchange Rate and International Adjustment in Wages, Prices, and Interest Rates: Japan Déjà Vu? CESifo Studies 52, 2, 276-303.

ZaKoian, J. (1994), Threshold Heteroskedastic Models, Journal of Economic Dynamics and Control 18, 931-955. 


\section{Appendix:}

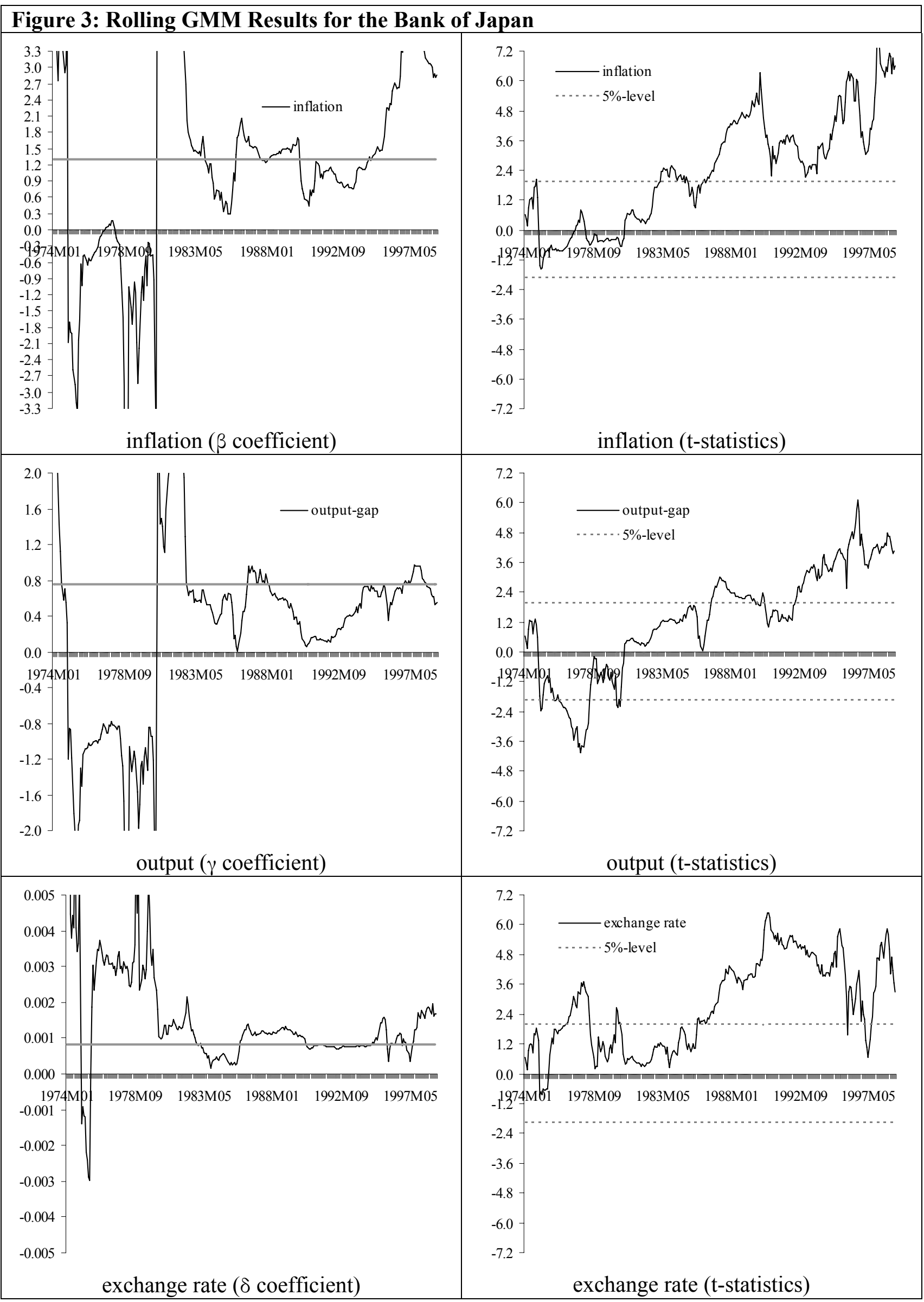

Note: Dark lines are the rolling coefficients. Solid grey lines in the panels on the left hand side indicate estimates for the full sample period from 1974:01 to 1999:03. Dashed grey lines on the right hand side indicate the $5 \%$-level of significance. 


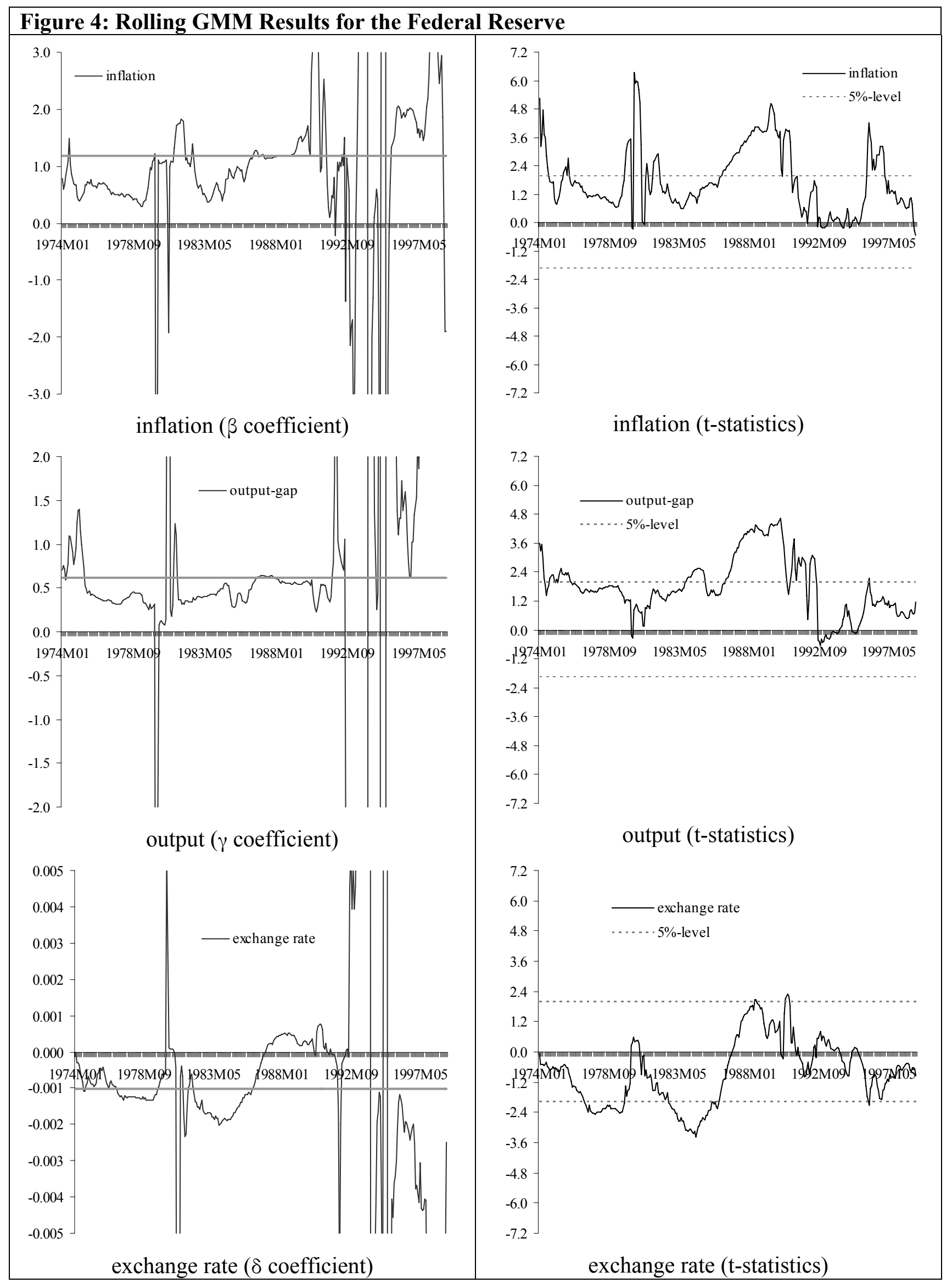

Note: Dark lines are the rolling coefficients. Solid grey lines in the panels on the left hand side indicate estimates for the full sample period from 1974:01 to 1999:03. Dashed grey lines on the right hand side indicate the 5\%-level of significance. 


\title{
CESifo Working Paper Series
}

\author{
(for full list see www.cesifo-group.de)
}

1988 Erkki Koskela and Rune Stenbacka, Equilibrium Unemployment with Outsourcing and Wage Solidarity under Labour Market Imperfections, May 2007

1989 Guglielmo Maria Caporale, Juncal Cunado and Luis A. Gil-Alana, Deterministic versus Stochastic Seasonal Fractional Integration and Structural Breaks, May 2007

1990 Cláudia Costa Storti and Paul De Grauwe, Globalization and the Price Decline of Illicit Drugs, May 2007

1991 Thomas Eichner and Ruediger Pethig, Pricing the Ecosystem and Taxing Ecosystem Services: A General Equilibrium Approach, May 2007

1992 Wladimir Raymond, Pierre Mohnen, Franz Palm and Sybrand Schim van der Loeff, The Behavior of the Maximum Likelihood Estimator of Dynamic Panel Data Sample Selection Models, May 2007

1993 Fahad Khalil, Jacques Lawarrée and Sungho Yun, Bribery vs. Extortion: Allowing the Lesser of two Evils, May 2007

1994 Thorvaldur Gylfason, The International Economics of Natural Resources and Growth, May 2007

1995 Catherine Roux and Thomas von Ungern-Sternberg, Leniency Programs in a Multimarket Setting: Amnesty Plus and Penalty Plus, May 2007

1996 J. Atsu Amegashie, Bazoumana Ouattara and Eric Strobl, Moral Hazard and the Composition of Transfers: Theory with an Application to Foreign Aid, May 2007

1997 Wolfgang Buchholz and Wolfgang Peters, Equal Sacrifice and Fair Burden Sharing in a Public Goods Economy, May 2007

1998 Robert S. Chirinko and Debdulal Mallick, The Fisher/Cobb-Douglas Paradox, Factor Shares, and Cointegration, May 2007

1999 Petra M. Geraats, Political Pressures and Monetary Mystique, May 2007

2000 Hartmut Egger and Udo Kreickemeier, Firm Heterogeneity and the Labour Market Effects of Trade Liberalisation, May 2007

2001 Andreas Freytag and Friedrich Schneider, Monetary Commitment, Institutional Constraints and Inflation: Empirical Evidence for OECD Countries since the 1970s, May 2007

2002 Niclas Berggren, Henrik Jordahl and Panu Poutvaara, The Looks of a Winner: Beauty, Gender, and Electoral Success, May 2007 
2003 Tomer Blumkin, Yoram Margalioth and Efraim Sadka, Incorporating Affirmative Action into the Welfare State, May 2007

2004 Harrie A. A. Verbon, Migrating Football Players, Transfer Fees and Migration Controls, May 2007

2005 Helmuth Cremer, Jean-Marie Lozachmeur and Pierre Pestieau, Income Taxation of Couples and the Tax Unit Choice, May 2007

2006 Michele Moretto and Paolo M. Panteghini, Preemption, Start-Up Decisions and the Firms’ Capital Structure, May 2007

2007 Andreas Schäfer and Thomas M. Steger, Macroeconomic Consequences of Distributional Conflicts, May 2007

2008 Mikael Priks, Judiciaries in Corrupt Societies, June 2007

2009 Steinar Holden and Fredrik Wulfsberg, Downward Nominal Wage Rigidity in the OECD, June 2007

2010 Emmanuel Dhyne, Catherine Fuss, Hashem Pesaran and Patrick Sevestre, Lumpy Price Adjustments: A Microeconometric Analysis, June 2007

2011 Paul Belleflamme and Eric Toulemonde, Negative Intra-Group Externalities in TwoSided Markets, June 2007

2012 Carlos Alós-Ferrer, Georg Kirchsteiger and Markus Walzl, On the Evolution of Market Institutions: The Platform Design Paradox, June 2007

2013 Axel Dreher and Martin Gassebner, Greasing the Wheels of Entrepreneurship? The Impact of Regulations and Corruption on Firm Entry, June 2007

2014 Dominique Demougin and Claude Fluet, Rules of Proof, Courts, and Incentives, June 2007

2015 Stefan Lachenmaier and Horst Rottmann, Effects of Innovation on Employment: A Dynamic Panel Analysis, June 2007

2016 Torsten Persson and Guido Tabellini, The Growth Effect of Democracy: Is it Heterogenous and how can it be Estimated?, June 2007

2017 Lorenz Blume, Jens Müller, Stefan Voigt and Carsten Wolf, The Economic Effects of Constitutions: Replicating - and Extending - Persson and Tabellini, June 2007

2018 Hartmut Egger and Gabriel Felbermayr, Endogenous Skill Formation and the Source Country Effects of International Labor Market Integration, June 2007

2019 Bruno Frey, Overprotected Politicians, June 2007 
2020 Jan Thomas Martini, Rainer Niemann and Dirk Simons, Transfer Pricing or Formula Apportionment? Tax-Induced Distortions of Multinationals' Investment and Production Decisions, June 2007

2021 Andreas Bühn, Alexander Karmann and Friedrich Schneider, Size and Development of the Shadow Economy and of Do-it-yourself Activities in Germany, June 2007

2022 Michael Rauscher and Edward B. Barbier, Biodiversity and Geography, June 2007

2023 Gunther Schnabl, Exchange Rate Volatility and Growth in Emerging Europe and East Asia, June 2007

2024 Erkki Koskela and Ronnie Schöb, Tax Progression under Collective Wage Bargaining and Individual Effort Determination, June 2007

2025 Jay Pil Choi and Marcel Thum, The Economics of Politically Connected Firms, June 2007

2026 Jukka Pirttilä and Roope Uusitalo, Leaky Bucket in the Real World: Estimating Inequality Aversion Using Survey Data, June 2007

2027 Ruslan Lukach, Peter M. Kort and Joseph Plasmans, Strategic R\&D with Knowledge Spillovers and Endogenous Time to Complete, June 2007

2028 Jarko Fidrmuc, Neil Foster and Johann Scharler, Labour Market Rigidities, Financial Integration and International Risk Sharing in the OECD, June 2007

2029 Bernardina Algieri and Thierry Bracke, Patterns of Current Account Adjustment Insights from Past Experience, June 2007

2030 Robert Dur and Hein Roelfsema, Social Exchange and Common Agency in Organizations, June 2007

2031 Alexander Libman and Lars P. Feld, Strategic Tax Collection and Fiscal Decentralisation: The Case of Russia, June 2007

2032 Øystein Foros, Hans Jarle Kind and Greg Shaffer, Resale Price Maintenance and Restrictions on Dominant Firm and Industry-Wide Adoption, June 2007

2033 Jan K. Brueckner and Kurt Van Dender, Atomistic Congestion Tolls at Concentrated Airports? Seeking a Unified View in the Internalization Debate, June 2007

2034 Viet Do and Ngo Van Long, International Outsourcing under Monopolistic Competition: Winners and Losers, June 2007

2035 Nadia Fiorino and Roberto Ricciuti, Determinants of Direct Democracy, June 2007

2036 Burkhard Heer and Alfred Maussner, Inflation and Output Dynamics in a Model with Labor Market Search and Capital Accumulation, June 2007 
2037 Konstantinos Angelopoulos, Jim Malley and Apostolis Philippopoulos, Public Education Expenditure, Growth and Welfare, June 2007

2038 Maarten Bosker, Steven Brakman, Harry Garretsen and Marc Schramm, Adding Geography to the New Economic Geography, June 2007

2039 Steffen Henzel, Oliver Hülsewig, Eric Mayer and Timo Wollmershäuser, The Price Puzzle Revisited: Can the Cost Channel Explain a Rise in Inflation after a Monetary Policy Shock?, July 2007

2040 Rosario Crinò, Service Offshoring and White-Collar Employment, July 2007

2041 Carsten Hefeker and Michael Neugart, Labor Market Regulation and the Legal System, July 2007

2042 Bart Cockx and Muriel Dejemeppe, Is the Notification of Monitoring a Threat to the Unemployed? A Regression Discontinuity Approach, July 2007

2043 Alfons J. Weichenrieder, Profit Shifting in the EU: Evidence from Germany, July 2007

2044 Annika Alexius and Bertil Holmlund, Monetary Policy and Swedish Unemployment Fluctuations, July 2007

2045 Axel Dreher, Jan-Egbert Sturm and Jakob de Haan, Does High Inflation Cause Central Bankers to Lose their Job? Evidence Based on a New Data Set, July 2007

2046 Guglielmo Maria Caporale and Luis A. Gil-Alana, Long Run and Cyclical Dynamics in the US Stock Market, July 2007

2047 Alessandro Balestrino, It is a Theft but not a Crime, July 2007

2048 Daniel Becker and Michael Rauscher, Fiscal Competition in Space and Time: An Endogenous-Growth Approach, July 2007

2049 Yannis M. Ioannides, Henry G. Overman, Esteban Rossi-Hansberg and Kurt Schmidheiny, The Effect of Information and Communication Technologies on Urban Structure, July 2007

2050 Hans-Werner Sinn, Please Bring me the New York Times - On the European Roots of Richard Abel Musgrave, July 2007

2051 Gunther Schnabl and Christian Danne, A Role Model for China? Exchange Rate Flexibility and Monetary Policy in Japan, July 2007 